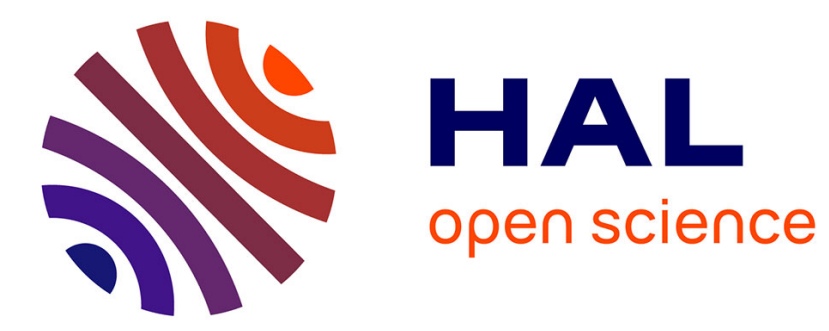

\title{
STABILIZATION OF HIGH-Tc Nb3Ge
}

\author{
J. Gavaler, M. Ashkin, A. Braginski, A. Santhanam
}

\section{To cite this version:}

J. Gavaler, M. Ashkin, A. Braginski, A. Santhanam. STABILIZATION OF HIGH-Tc Nb3Ge. Journal de Physique Colloques, 1978, 39 (C6), pp.C6-400-C6-401. 10.1051/jphyscol:19786179 . jpa-00217593

\section{HAL Id: jpa-00217593 https://hal.science/jpa-00217593}

Submitted on 1 Jan 1978

HAL is a multi-disciplinary open access archive for the deposit and dissemination of scientific research documents, whether they are published or not. The documents may come from teaching and research institutions in France or abroad, or from public or private research centers.
L'archive ouverte pluridisciplinaire HAL, est destinée au dépôt et à la diffusion de documents scientifiques de niveau recherche, publiés ou non, émanant des établissements d'enseignement et de recherche français ou étrangers, des laboratoires publics ou privés. 
STABILIZATION OF HIGH-T $\mathrm{Nb}_{3} \mathrm{Ge}^{*}$

J.R. Gavaler, M. Ashkin, A.I. Braginski and A.T. Santhanam

Westinghouse Research and Development Center, Pittsburgh, Pennsylvania, 15235, U.S.A.

Résumé.- Les résultats d'analyses physiques nous font croire que la croissance de $\mathrm{Nb}_{3} \mathrm{Ge}$ stoechiométrique se fait par homoépitaxie sur une phase A15 de Nb-Ge qui se forme près de l'interface avec le substrat et a une constante de réseau augmentée grâce à la présence des impuretés.

Abstract.- From analytical results we hypothesize that stoichiometric $\mathrm{Nb}_{3} \mathrm{Ge}$ is formed through a homoepitaxial process form an Al5 $\mathrm{Nb}$-Ge phase having an impurity expanded lattice formed near the interface.

INTRODUCTION.- High- $\mathrm{T}_{\mathrm{c}} \mathrm{Nb}_{3} \mathrm{Ge}\left(\mathrm{T}_{\mathrm{c}} \sim 22 \mathrm{~K}\right)$ can now be formed by low-energy sputtering /1/ chemical vapor deposition (CVD) $/ 2 /$ and coevaporation /3/. These high-T films which crystallize in the Al5 structure are close to or have the ideal $3 / 1$ composition, and have a lattice parameter $\sim 5.14 \AA$. Substantial evidence indicates that impurities enter in a beneficial way in forming high-T $\mathrm{Nb}_{3} \mathrm{Ge} / 4-6 /$. However, with no deliberate introduction of impurities, epitaxial growth on $\mathrm{Nb}_{3} \mathrm{Ir}$ also produced high-T $\mathrm{T}_{\mathrm{C}} \mathrm{Nb}_{3} \mathrm{Ge}$ films $17 /$. Thus the role of impurities in forming high-T $\mathrm{Nb}_{3} \mathrm{Ge}$ remains unresolved.

To try to resolve this question we have been investigating the initially nucleated material in high-T $T_{c}$ sputtered and CVD Nb-Ge films. Based on these results we present a hypothesis which we believe explains the importance of impurities to the -ormation of the high-T $\mathrm{Tb}_{3}$ Ge phase.

EXPERIMENTAL PROCEDURE.- The Nb-Ge films for this study wer made by sputtering and CVD according to methods previous 1 y described $/ 1,2 /$. Substrates used were sapphire, Hastelloy $B$, tantalum and vanadium. In some cases, the tantalum and vanadium substrates were first oxidized by heating in air for several minutes at $\sim 600^{\circ} \mathrm{C}$. Superconducting $T_{c}$ 's of the films were determined by a standard four-point resistance technique using germanium thermometry. Composition analyses were done by Auger and Secondary Ion Mass Spectroscopy (SIMS). Structural analyses was by transmission electron microscopy (TEM).

RESULTS. - We have found that in sputtered $\mathrm{Nb}_{3} \mathrm{Ge}$,

* Supported in part by AFOSR Contract No. F49620$78-\mathrm{C}-0031$. none of the films of $1000 \AA$ or less had the maximum critical temperatures of between 22 and $23 \mathrm{~K}$ measured in thicker films. Tarutani and Kudo /8/ have reported similar results for their coevaporated $\mathrm{Nb}_{3} \mathrm{Ge}$ films. Chemical analysis of sputtered film has previously shown the presence of oxygen throughout these films with the concentration near the interface being very high (of the order of one oxygen atom per $\mathrm{Nb}_{3} \mathrm{Ge}$ unit) and thereafter decreasing with increasing distance from the interface down to a constant level of about 1 at. \% in the body of the film. Analyses of CVD films on the other hand showed that there was no oxygen in the body of these films at least down to the 0.1 at. \% detection limit of the Auger apparatus used for the analysis. However the analysis did show a sharp oxygen peak at the interface similar to that observed in the sputtered films. To try to determine the significance of this oxygen peak, a series of $\mathrm{Nb}_{3} \mathrm{Ge}$ films were sputtered onto alumina, tantalum, and vanadium substrates under similar conditions. Since tantalum and vanadium both have a strong affinity to oxygen, it was reasoned that any oxygen that would be present on these substrates would tend to react with the metal therefore decreasing the possibility of its being incorporated into the initially nucleated films. The results of these experiments showed that whereas the $\mathrm{Nb}-\mathrm{Ge}$ film deposited onto the alumina substrates had typically high-T onsets of $\sim 22 \mathrm{~K}$, and widths $\Delta \mathrm{T}_{\mathrm{c}}$ 's of $\sim 1 \mathrm{~K}$, the films on $\mathrm{V}$ and $\mathrm{Ta}$ had onsets of only about $13 \mathrm{~K}$ and $\Delta \mathrm{T}_{c}$ 's of 3 to $4 \mathrm{~K}$. The deposition experiments were then repeated using vanadium and tantalum substrates which were first oxidized. With these substrates high-T ${ }_{c}$ 's could be obtained similar to those on alumina. An oxygen 
profile from SIMS for a high-T $(\sim 21.5 \mathrm{~K})$ film deposited on an oxidized tantalum substrate is similar to all of the other high-T films that we have analysed, i.e., the level is highest at the interface and then drops off in the body of the film. This type of profile is not observed in the lower-T film deposited on the tantalum substrate; instead the oxygen is low at the interface and increases in the body of the film. These results again point toward the initially nucleated material as being crucial toward achieving high-T ${ }_{c}$ 's.

To investigate this initially nucleated material transmission electron analyses were made on three very thin (< $1000 \AA$ ) sputtered films on sapphire substrates. These films had $T_{c}$ onsets of 14 , 16 , and $17 \mathrm{~K}$ which were the highest values observed for the particular film thicknesses. the $\Delta \mathrm{T}_{\mathrm{c}}$ were $\sim 2 \mathrm{~K}$. The structure of a representative film with a $T_{c}$ onset of $14 \mathrm{~K}$ and thickness of $\sim 700 \AA$ is characterized by extremely fine grains with the grains being clean with no substructure. From the selected area diffraction (SAD) pattern d-spacings were calculated. Most of the observed reflections could be identified as belonging to the $A 15 \mathrm{Nb}_{3} \mathrm{Ge}$ phase. An unexpectedly large lattice parameter, $a_{0}$ of $5.25 \mathrm{~A}$ was calculated for this phase. Similarly large $a_{o}$ 's were also found for the other two film studied.

DISCUSSION.- From these observations, we propose the following hypothesis : during the initial $1000 \mathrm{~A}$ of growth a $\mathrm{Nb}_{3}$ Ge phase is formed which is at or close to $3 / 1$ stoichiometry but which has a much larger lattice parameter than is usual for stoichiometric $\mathrm{Nb}_{3} \mathrm{Ge}(\sim 5.25 \AA$ compared to $\sim 5.14$ A). We believe that because of this large lattice parameter, this phase having $3 / 1$ stoichiometry is stable and continues to grow without decomposing into a two-phase mixture as would otherwise occur. This concept is consistent with other data on A15 structure superconductors having the general formula $\mathrm{Nb}_{3} \mathrm{X}$ (where $\mathrm{X}=\mathrm{Sn}, \mathrm{Al}, \mathrm{Ga}$, or $\mathrm{Ge}$ ) wherein the A15 lattice becomes progressively more unstable as the cell size decreases. The boundary between a stable and unstable lattice appears to be when $a_{0}$ is $\sim 5,17 \AA$. Continuing with the hypothesis, we believe that as the film growth proceeds by "homoepitaxy", the A15 lattice gradually becomes smaller until it achieves a cell edge commensurate with its
$3 / 1$ composition and with the size of the constituent $\mathrm{Nb}$ and $\mathrm{Ge}$ atoms, i.e., $\mathrm{a}_{0} \sim, 5.14 \AA$. Because of its now small lattice parameter (small $\mathrm{Nb}-\mathrm{Nb}$ distances) its $T_{c}$ reaches the very high value of $~$ 22 to $23 \mathrm{k}$. Accepting this picture one can now see that the function of the impurities during the first $1000 \AA$ of growth must be, in some way, to expand the lattice of the stoichiometric $\mathrm{Nb}_{3} \mathrm{Ge}$ phase sufficiently to allow it to be stable. One may speculate that this is accomplished by one of the following ways : The presence of a large number of interstitial impurities in the A15 lattice could produce the necessary expansion, or possibly the presence of impurities during nucleation could cause the formation of very fine Al5 grains. If these grains were sufficiently small, the lattice could conceivably relax sufficiently to produce the necessary expansion. In either case, as the impurity level decreases, the lattice gradually would be a1lowed to shrink to its normal dimensions. In the case where one uses an A15 substrate such as $\mathrm{Nb}_{3} \mathrm{Ir}$, the necessity of first forming a stable stoichiometric Als layer would no longer be required since the epitaxial growth process would commence immediately on the original substratematerial. Although at present all of our results appear to support this hypothesis a more complete analysis of a signifi cant number of $\mathrm{Nb}_{3}$ Ge films will be required before one can make a final judgment regarding its validity.

\section{References}

/1/ Gavaler, J.R., App1. Phys. Lett. 23 (1973) 480.

/2/ Braginski, A.I. and Roland, G.W., App1. Phys. Lett. 25 (1974) 762 .

/3/ Hammond, R.H., IEEE Trans. MAG-11, No. 2 (1975) 201.

14/ Gavaler, J.R., in Superconductivity in $d-$ and f-Band Metals (Proc. of 2nd Rochester Conf.) D.H. Douglas, Ed. (1976) 421 .

/5/ Hallak, A.B., Hammond, R.H., Geballe, T.H. and Zubeck, R.B., IEEE Trans. MAG-13, No. 1 (1977) 311 .

16/ Sigsbee, R.A., IEEE Trans. MAG-13, No. 1 (1977) 307.

/7/ Dayem, A.H., Geballe T.H., Zubeck, R.B., Hallak, A. B. and Hul1, G.W., Jr., Appl. Phys. Lett. 30 (1977) 541 .

/8/ Tarutani, Y. and Kudo, M., Jpn. J. Appl. Phys. 16 (1977) 509. 